\title{
Stationary phases for peptide analysis by high performance liquid chromatography: a review
}

\author{
Karel Štulík ${ }^{a, *}$, Vẽra Pacákováa ${ }^{a}$ Jana Suchánkováa, Henk A. Claessens ${ }^{b}$ \\ ${ }^{a}$ Department of Analytical Chemistry, Charles University, Albertov 2030, 12840 Prague 2, Czech Republic \\ baboratory of Instrumental Analysis, Technical University, Eindhoven, Netherlands
}

\begin{abstract}
A survey is given of modern stationary phases employed in high performance liquid chromatography (HPLC) analysis of peptides. The physico-chemical properties of peptides and their consequences for the selection and optimization of the separation system are briefly discussed, followed by a summary of the approaches to the selection and characterization of stationary phases. The properties and applicability of various stationary phases are then critically reviewed, including aspects such as size-exclusion, ion-exchange, reversed-phase, hydrophobic-interaction, affinity and chiral systems, as well as some specialized separation techniques. Emphasis is placed on the most recent literature. (C) 1997 Elsevier Science B.V.
\end{abstract}

Keywords: Peptides; HPLC; Stationary phases

\section{Introduction}

The immense importance of peptides for living beings is well known and thus a great variety of them have been isolated from natural materials or synthesized, studied and applied in biology, medicine, biotechnology and agriculture. Separations play a key role in the field and are used both in the preparative and the analytical mode. It should be pointed out that even purely analytical procedures must often combine preparative and analytical separation steps, because of the complexity of the materials studied; therefore, some preparative aspects will also be discussed in this review.

Peptide analysis has numerous applications. It has been used to establish the identity and purity of

*Corresponding author. peptide preparations in all the steps of peptide isolation from natural matrices or during synthesis, to check the purity of peptide products, such as pharmaceuticals, to determine peptides in various matrices, e.g. in medicine, biology or agriculture and, particularly notable, in peptide mapping, i.e., to elucidate protein primary structure. The analytical procedures employed are complex and often combine several chromatograpic modes (e.g., size-exclusion chromatography (SEC) followed by reversed-phase chromatography (RPC)) with other separation methods (e.g., capillary electrophoresis (CE)) and with bio- and immuno-chemical steps.

In a critical survey of the properties of HPLC stationary phases and their applications in peptide analysis, two important facts should be borne in mind: the selection of a stationary phase is part of the approach to the whole analytical problem and cannot 
Table 1

List of columns for the RP, SEC, IEC and HIC separations of peptides and proteins

\begin{tabular}{|c|c|}
\hline Column name & Supplier \\
\hline \multicolumn{2}{|l|}{$\mathrm{RP}$} \\
\hline Lichrospher $500 \mathrm{CH}-8$ & Merck, Darmstadt, Germany \\
\hline Lichrospher 100 PR-18 & idem \\
\hline Hy-Tack C-18 & Glycotech, Hamden, CT, USA \\
\hline Vydac C-18 & The Separations Group, Hesperia, CA, USA \\
\hline Zorbax SB 300 C-8 & Rockland Technologies, Newport, DE, USA \\
\hline Zorbax 300 SB-C18 RR & idem \\
\hline Synchropak RP-P C-18 & Synchrom, Linden, IN, USA \\
\hline Aquapore OD-300 & Applied Biosystems, San Jose, CA, USA \\
\hline Hypersil C18-WP 300 & Hypersil, Runcorn, UK \\
\hline Hypersil Peptide & idem \\
\hline Kromasil $100-\mathrm{C} 8, \mathrm{C}-18$ & EKA Chemicals, Bohus, Sweden \\
\hline Bakerbond WP C-18 & J.T. Baker B.V., Deventer, NL. \\
\hline Separon Hema S-1000 RP-18 & Tessek, Prague, Cz. Republic \\
\hline Develosil NP-ODS & Nomura Chemicals, Seto-City, Japan \\
\hline Develosil 300 ODS -7 & idem \\
\hline Jupiter $300 \mathrm{C}-18$ & Phenomenex, Torrance, CA, USA \\
\hline Symmetry C-18 & Waters Corp., Milford, MA, USA \\
\hline Nucleosil 300-5 C-18 MPN & Macherey and Nagel, Düren, Germany \\
\hline \multicolumn{2}{|l|}{ SEC } \\
\hline BioSil SEC 250 & BioRad, Richmond, CA, USA \\
\hline Superdex $200 \mathrm{HR}$ & Pharmacia, Uppsala, Sweden \\
\hline Tosohaas TSK & Tosohaas, Montgomeryville, PA, USA \\
\hline HEMA-Bio 1000 & Tessek, Prague, Cz. Republic \\
\hline Protein-Pak DEAE $15 \mathrm{HR}$ & Waters Corp., Milford, MA, USA \\
\hline Protein-Pak SP 8 HR & idem \\
\hline PolySep-GFC-P & Phenomenex, Torrance, CA, USA \\
\hline Shodex OH Pak Q801 & idem \\
\hline Zorbax GF 250/450 & Rockland Technologies, Newport, DE, USA \\
\hline Zorbax PSM & idem \\
\hline \multicolumn{2}{|l|}{ IEC } \\
\hline Zorbax SCX, WCX & Rockland Technologies, Newport, DE, USA \\
\hline Bakerbond Abx & J.T. Baker B.V., Deventer, NL \\
\hline HEMA-BIO 100 DEAE & Tessek, Prague, Cz. Republic \\
\hline Shodex Asahipak GSHQ & Phenomenex, Torrance, CA, USA \\
\hline Mitsubishi Chemical CK 10 & idem \\
\hline Nucleogel SAX 100-8 & Macherey and Nagel, Düren, Germany \\
\hline \multicolumn{2}{|l|}{$\mathrm{HIC}$} \\
\hline Spherogel CAA HIC & Beckman, San Ramon, CA, USA \\
\hline TSK-Phenyl 5-PW & idem \\
\hline Synchropak-Propyl & Synchrom, Linden, IN, USA \\
\hline Alkyl-Superox HR & Pharmacia, Uppsala, Sweden \\
\hline Zorbax SB $300 \mathrm{CN}$ & Rockland Technologies, Newport, DE, USA \\
\hline Zorbax SB $300 \mathrm{C} 3$ & Rockland Technologies, Newport, DE, USA \\
\hline Aquapore Butyl & Applied Biosystems, San Jose, CA, USA \\
\hline Separon HEMA-Bio 1000 Phenyl & Tessek, Prague, Cz. Republic \\
\hline Kovasil-H & Chemie, Uetikon, Switzerland \\
\hline Nucleosil 5 C-18 & Macherey and Nagel, Düren, Germany \\
\hline
\end{tabular}


be considered separately from the choice and optimization of the mobile phase and of the basic experimental conditions; detailed information on the physico-chemical character and properties of commercial stationary phases is often difficult or impossible to obtain, as this vital information tends to be a trade secret. Therefore, a critical comparison of various commercial columns is subject to a great many limitations. The present review concentrates on recent developments. The literature is extensive, varied and scattered; we have tried to select the most important new works in the field (numerous further references can be found in the publications cited). This paper is not intended to give an exhaustive survey of commercial columns. However, some typical examples are listed in Table 1.

\section{Character and basic properties of peptides}

Peptides constitute an extensive class of compounds and thus their properties vary considerably and place great demands on suitable selection of separation systems and their versatility. It is conventionally accepted that peptides are compounds containing two to fifty amino acid residues [1]. Dipeptides are still small molecules with molecular weights of the order of hundreds, whereas large peptides, with molecular masses of several thousands, have properties characteristic of proteins. There are substantial differences in the chromatographic behaviour of small molecules with one or a few active sites for interaction with the mobile and stationary phases and that of large molecules with many active sites. Moreover, the danger of denaturing of large peptides is very important from a biological point of view and places additional demands on the selection of the chromatographic system and the speed of separations.

The properties of the smallest peptides are similar to those of individual amino acids: their chromatographic behaviour is determined by the character of their side chains and substituent groups, i.e., the strength of the basic and acidic ionizable groups present, and also by the degree of hydrophobicity or hydrophilicity. Therefore, they exhibit isoelectric points and their retention is strongly dependent on the $\mathrm{pH}$. With increasing number of amino acid residues, the importance of the peptide primary structure (amino acid composition and sequence) increases. With more than about 15 amino acid residues, secondary (and progressively tertiary and quaternary) structures begin to play a role and the conformation of the largest peptides can decisively affect their retention behaviour.

In view of these peptide properties, RPC is the most versatile mode of chromatography, as it enables the use of both the acid-base and hydrophobic/hydrophilic properties of the analytes. Problems sometimes arise in connection with the denaturing of large peptides due to the high hydrophobicity of the stationary phase and low polarity of the mobile phase. Classical ion-exchange chromatographic (IEC) procedures can also be applied to a wide range of peptide sizes; however, they tend to exhibit somewhat poorer separation efficiencies compared to RPC and large peptides may be very strongly sorbed, due to the presence of many active sites in the analyte molecule. Size-exclusion chromatography (SEC) can be very useful in preseparations of complex mixtures into smaller groups of analytes that are then further separated by another technique. In addition, much more specialized procedures can be used: hydrophobic-interaction chromatography (HIC), which has the advantage that the conditions are mild (moderate hydrophobicity and low ligand density of the stationary phase, aqueous mobile phases with high ionic strength), so that the danger of peptide denaturation is suppressed; other important techniques include affinity chromatography and chiral separations.

Numerous works have been devoted to correlation of the retention behaviour of peptides with their properties, in order to predict suitable conditions for chromatographic separations. It has been shown [2] that an $\alpha$-amino group substantially affects the retention behaviour of peptides in RPC. This study of synthetic deca-peptides demonstrates that the $\mathrm{p} K_{\mathrm{a}}$ values of the amino groups and of the ionizable side chains in peptides are very similar to those found for proteins and very dissimilar to those found for the corresponding amino acids, i.e. the hydrophobic RPC stationary phase creates an environment very similar to the hydrophobic environment of proteins. Tables of $\mathrm{p} K_{\mathrm{a}}$ values and hydrophobicity data are given in the paper. The shifts in the ionization constants of amino acids and peptides in micellar media have been discussed [3]. A scale of peptide hydrophobicities has 
been obtained from RPC data [4]. On the basis of the RPC retention data for 104 peptides, a model has been developed for prediction of peptide retention [5], while the effects of the peptide secondary structure on the retention thermodynamics is described in Ref. [6]. A number of papers employed various methods for statistical treatment of extensive sets of peptide retention data for predictive purposes (see, e.g., Refs. [7,8]; for a good survey see Refs. $[9,10])$. A model has been given for electrostatic interaction of proteins [11] that is also applicable to large peptides.

\section{Approaches for column selection and testing}

When selecting a column for a given separation, many factors must be considered, which include primarily the general suitability for the type of sample and purpose of the separation, sufficiently high efficiency and resolution (support particle size, shape and porosity and its ability to bind a sufficient concentration of suitable active species), the chemical and mechanical stability of the support and the stationary phase itself under the particular separation conditions and reasonable speed and cost of the separation. In peptide analyses, some additional aspects should be considered, namely:

- It is usually necessary to suppress denaturing of the solutes; this places limitations on the composition of the separation systems, chiefly their hydrophobicity, and increases the need for rapid separations.

- Because of the complexity of the mixtures to be separated, very high resolution is required: one of the most important causes of poor resolution is slowness of mass transport and of sorption/desorption processes; these can be hastened by work at elevated temperatures and by choosing stationary particle types that permit rapid solute transport. In addition, large peptide molecules with many active sites behave differently from small molecules: the capacity factors change much more rapidly with a change in the content of the organic modifier in RPC and the steepness of this dependence increases with increasing size of the solute molecule; thus gradient elution must usually be employed and the conditions must be carefully optimized. Then the resolution does not greatly depend on the column length and mobile phase flow rate and consequently short columns and high flow rates can be employed to advantage (e.g., [12]).

- Stationary phase particle size does not strongly affect the separation efficiencies for large peptides and thus large non-porous particles (up to $20 \mu \mathrm{m}$ ) have been used with efficiencies analogous to those obtained with 2 to $5 \mu \mathrm{m}$ particles [13].

All the above aspects must be taken in consideration when choosing a separation system (also considering, of course, the requirements of the detection technique used). Any stationary phase plus its support exhibits more than one type of interaction with the given solutes and the components of the mobile phase. Sometimes we can use the fact that a column has, e.g., both hydrophobic and ion-exchange properties for finer tuning of the separation conditions and for tailoring the column properties to a particular application; of course, prediction of the column performance and optimization of the conditions to be used are then much more difficult. In other systems it is necessary to suppress side interactions in order to obtain meaningful results: in SEC, the ion-exchange effects should be suppressed, e.g. by adding salts to the mobile phase. To test for the presence of more than one kind of interaction and for departures of separation systems from ideal behaviour, series of synthetic peptides have been proposed [14-17] (Table 2).

The selection and testing of a column is still not a simple process and is often carried out on the basis of very subjective criteria and personal experience, as there are many columns on the market, information on the separation mechanisms is limited and much vital information is not disclosed by the manufacturers. Furthermore, even materials that are nominally identical often exhibit manufacturer-to-manufacturer and even batch-to-batch differences in their behaviour under identical experimental conditions. The growing need for validated experimental procedures stresses the necessity of creating a more rational and unified basis for the procedures of selection and testing of the columns.

A discussion of the problems of testing the column lifetime and the reproducibility of the properties of commercial materials can be found in Refs. $[18,19]$. 
Table 2

Peptide standards for monitoring of ideal and non-ideal behaviour in SEC, IEC and RPC [14-17]

\begin{tabular}{|c|c|c|c|c|}
\hline & Peptide sequence & No. of repeating units(n) & No. of residues & Net charge \\
\hline \multirow[t]{5}{*}{ SEC+IEC } & Ac-(Gly-Leu-Gly-Ala-Lys-Gly-Ala-Gly-Val-Gly) ${ }_{n}$-amide & 1 & 10 & 1 \\
\hline & Ac-(Gly-Leu-Gly-Ala-Lys-Gly-Ala-Gly-Val-Gly) $)_{n}$-amide & 2 & 20 & 2 \\
\hline & Ac-(Gly-Leu-Gly-Ala-Lys-Gly-Ala-Gly-Val-Gly) $)_{n}$-amide & 3 & 30 & 3 \\
\hline & Ac-(Gly-Leu-Gly-Ala-Iys-Gly-Ala-Gly-Val-Gly) $)_{n}$-amide & 4 & 40 & 4 \\
\hline & Ac-(Gly-Leu-Gly-Ala-Lys-Gly-Ala-Gly-Val-Gly) $)_{n}$-amide & 5 & 50 & 5 \\
\hline \multirow[t]{4}{*}{$\mathrm{IEC}+\mathrm{RPC}$} & Ac-Gly-Gly-Gly-Lcu-Gly-Gly-Ala-Gly-Gly-Lcu-Lys-amidc & - & 11 & 1 \\
\hline & Ac-Gly-Gly-Gly-Leu-Gly-Gly-Ala-Gly-Gly-Leu-Lys-amide & - & 11 & 2 \\
\hline & Ac-Gly-Gly-Gly-Leu-Gly-Gly-Ala-Gly-Gly-Leu-Lys-anide & - & 11 & 3 \\
\hline & Ac-Gly-Gly-Gly-Leu-Gly-Gly-Ala-Gly-Gly-Leu-Lys-amide & - & 11 & 4 \\
\hline
\end{tabular}

The column performance can be tested by either chromatographic or non-chromatographic methods $[21,22]$; methods of the former group are usually preferable, as they provide more direct information on the chromatographic performance of the column and also on its changes on ageing.

Many procedures have been proposed for column testing, most of them employing chemically modified silica phases which are by far the most common in contemporary HPLC; however, none of these procedures has gained general acceptance. The major applications of these phases are in RPC and HIC permitting very varied separations $[20,23-25]$ and there is a wide range of commercial columns of this type on the market; in addition, most evaluation and testing procedures have been designed for these phases. They can be classified into four groups:

- Semiempirical methods, such as those of Engelhardt [26], Walters [27], Tanaka [28] and Bidlingmeyer [29].

- Model-based methods, such as the calculation model of Galushko [30], the silanol scavenging model of Horváth et al. [31], or the interaction index approach of Jandera [32].

- Statistical evaluation methods employing, e.g., principal component analysis (PCA), cluster analysis (CA) and factor analysis [33,34].

- Thermodynamic methods, e.g., the use of Van't Hoff plots [35].

The evaluation methods of the former two groups generally classify columns in terms of parameters such as hydrophobicity, hydrophilicity, silanol activity and the carbon percentage in the packing material. Methods in the third group are often used to group columns with similar properties, whereas a thermodynamic evaluation is chiefly employed in order to determine whether a separation process is driven by enthalpic rather than entropic factors.

The present situation in the testing of RPC and HIC columns is far from satisfactory and the results obtained are often difficult to interpret or are even contradictory [36-38]. This partly stems from the very different principles and assumptions employed in the individual testing methods and further from the fact that a great variety of test substances, mobile phase compositions and calculation procedures are used. For example, it has been shown [20] that column parameters such as hydrophobicity and hydrophilicity strongly depend on the nature of the test substance. Unfortunately, inappropriate test substances are sometimes selected when testing columns for peptide and protein analysis, usually small molecules whose behaviour is very different from that of large peptide and protein species. It is thus imperative to choose test substances that are as similar as possible to the substances to be separated.

The isopotential concept of Bidlingmeyer [29] and the slope-intercept relationships (log of retention factor versus salt molality (HIC) or per cent of organic modifier (RPC)) were recently examined for HIC and RPC [20,23,39], in order to evaluate columns for peptide and protein analysis. The results have been partially confirmed using other testing methods but discrepancies have also been discovered. 


\section{A survey of stationary phases for peptide separations}

In view of the high demands placed on peptide separations, the stationary phase development is a very active area. RPC is still the most widespread technique, but the stress on combination of various HPLC modes within one procedure (e.g., RPC, IEC, SEC) is constantly growing [40], as is the emphasis on combination of HPLC with other separation techniques - see, e.g., the combination of preparative RPC with analytical RPC, capillary electrophoresis (CE) and micellar electrokinetic chromatography (MEKC) for the purification and characterization of a new family of peptides from the human neuro-endocrine system [41]. In the subsequent text more general aspects of supports and their modifications are discussed first, followed by a discussion of the specific features of the individual chromatographic modes.

\subsection{Supports and their modification}

Both completely porous and pellicular supports are used in peptide separations; the classical silica materials are used most extensively. A pore size of $100 \AA$ is commonly recommended for this purpose, but wider pore materials ( $300 \AA$ ) should be preferred [42] in separations of large peptides in order to eliminate size exclusion effects. The support surface area is important for the retention of linear peptides containing ca. 25 or more residues; materials with $300 \AA$ pores have smaller surface areas, about $100 \mathrm{~m}^{2} \mathrm{~g}^{-1}$, compared with those containing $100 \AA$ pores (ca. $170 \mathrm{~m}^{2} \mathrm{~g}^{-1}$ ).

Non-porous silica packing materials were recently described and their properties discussed (for a review see $[43,44]$ ). These materials actually have very narrow pores of 2 to $4 \AA$ that are inaccessible for solutes; moreover, they can be eliminated, e.g., by calcination at $800 \mathrm{~K}$ followed by rehydroxylation of the material. A drawback of non-porous materials is their extremely small outer surface area, two orders of magnitude lower than that of porous packings (for a solid density of $2.2 \mathrm{~g} \mathrm{ml}^{-1}$, the surface area varies from 0.6 to $6 \mathrm{~m}^{2}$ for particle diameters from 5 to $0.5 \mu \mathrm{m}$, respectively). This leads to low retention and mass loadability values. Therefore, very small particles must be used to pack the columns. However, these materials then have numerous advantages, namely,

- they exhibit fast mass transport as restricted pore diffusion is eliminated;

- enthalpic and entropic exclusion of solutes occurring with porous packings is absent;

- surface accessibility is high;

- ligands bound to the surface have a controlled topography;

- short residence times of solutes in the column are beneficial for suppression of denaturing effects and preservation of the biological activity of the solutes;

- columns packed with very small particles have minimal void volumes; this decreases the consumption of solvents and minimizes susceptibility to compression during the packing procedure.

Non-porous particles are then modified by silanization or by polymer coating. A different approach can also be taken [45], involving deposition of silica ultramicrospheres $(0.3$ to $0.9 \mu \mathrm{m}$ i.d.) on spherical polymer beads. In contrast to common procedures, in which silica gel is first chemically modified with an alkyl silane and then the remaining free silanol groups are endcapped with trimethyl chlorosilane, here the silica gel is first coated with a reactive polymer film and then alkylated. This procedure effectively endcaps the free silanol groups.

The performance of totally porous and pellicular sorbents has been compared [46]. It has been found that micropellicular sorbents, e.g., Hy-Tach C-18 consisting of $2 \mu \mathrm{m}$ fused-silica beads coated with a thin porous octadecyl layer, exhibit a high thermal stability and can thus be used at elevated temperatures, but have poorer (about three times lower) loading capacity and a lower phase ratio compared with porous sorbents. Columns with porous sorbents require stronger eluents, i.e., with higher organic modifier contents, than pellicular sorbents, because of their higher phase ratio.

The use of silica-based packings is limited to applications employing acidic and neutral mobile phases. To overcome this limitation, a number of other materials have been proposed as supports, consisting of either inorganic oxides or polymers. 'litanium and zirconium dioxides and aluminium oxide have been 
shown to be hydrolytically very stable and useful for the preparation of lipophilic (and possibly other) phases $[47,48]$. Titanium and zirconium dioxides form highly spherical, porous particles, the matrix is crystalline, in contrast to silica gel, and thus the surface is very homogeneous. Porous zirconium dioxide particles have been modified using various derivatization procedures. Silanes have been immobilized on the surface in order to introduce hydrophobic ligands and reactive groups, e.g. octadecyl, a carbohydrate and Cibacron Blue F3GA [49], and affinity ligands, the iminodiacetic acid-Cu(II) chelate and the lectin concanavalin A [50]. These phases are stable up to high $\mathrm{pH}$ values of 10.5 , 12 and 13 for Cibacron Blue, carbohydrates and C18 , respectively. A Langmuir-type isotherm was obtained when using affinity ligands indicating that the sorption is controlled by a single interaction type and that non-specific interactions with the support are negligible. Polymer-coated zirconium dioxide particles have also been prepared [49], using polybutadiene or by cross-linking a carbohydratemodified sorbent; however, it has been shown [51] that proteins are irreversibly adsorbed on polybutadiene-coated zirconium dioxide, due to the high hydrophobicity of polybutadiene plus the presence of strong Lewis acid sites on the zirconium dioxide surface.

Supports based on organic polymers also eliminate the principal drawback of silica gel, its limited $\mathrm{pH}$ range, and bring other advantages, such as shorter runto-run re-equilibration times and better cleaning ability. On the other hand, they usually exhibit poorer separation efficiencies (and thus also poorer peak capacities) and are mostly inferior to inorganic supports in mechanical strength. Nevertheless, some of them have yielded good results in many types of separation.

HEMA (a copolymer of ethylene dimethacrylate and hydroxyethyl methacrylate) [52] is biocompatible and was originally developed as a material for soft contact lenses. It is highly resistant to hydrolysis and microbial attack and has a high mechanical strength and a high concentration of surface hydroxyl groups. This material exhibits mixed hydrophilic-hydrophobic properties because of the long, hydrophobic $\mathrm{C}-\mathrm{C}$ polymer backbone chain and the presence of hydrophilic $\mathrm{OH}$ groups and is thus readily modified and applicable to SEC, RPC, IEC, HIC and various modes of affinity chromatography.

Polymers are also useful for the preparation of large-particle permeable supports, in which the mobile phase perfuses through the large pores [53-57]. In these phases (e.g., POROS Q/M and Q HYPER D), mass transport within the particles occurs through convection and is thus very fast and very rapid separations are possible (e.g., 3 min separation of human fibrinogen on RPC phase POROS 20-R2 compared with 25 min with conventional RPC) [58].

Commonly used particle-packed columns have relatively large void volumes (e.g., $10 \mu \mathrm{m}$ silica sorbent beads occupy a maximum of $74 \%$ of the column volume) and thus attempts have been made to decrease the void volume value. This parameter can be decreased to ca. $9 \%$ when using porous silica hollow fibres and to negligible values with cellulose sheets. Another way of suppressing the void volume is to fill the column completely with a separation medium (continuous separation medium, molded or rod columns). Such a polymeric rod has large pores (of the order of $1 \mu \mathrm{m}$ ) and is readily permeable for the mobile phase, which thus flows through a homogeneous medium. Convective mass transport permits rapid separations with efficiencies that are almost independent of the mobile phase flow rate and proceed at small hack pressures.

Hjertén et al. [59-62] prepared rod columns from swollen polyacrylamide gels. Polymerization can be carried out directly in the column [63-67] or membranes can be prepared from a suitable polymer, placed in a cartridge and used for rapid separations [68]. These media are primarily intended for fast separations of proteins, but bradykinin and D-Phe ${ }^{7}$ bradykinin can also be separated within 3 min with a sufficient efficiency of 97900 plates/m [65]. Continuous beds for IEC have been prepared in fused silica tubings of up to $10 \mu \mathrm{m}$ in diameter [66]. The beds are produced in the form of rods traversed by channels through which the eluent passes. The walls of the channels are composed of small particles and are impermeable to peptides, permitting rapid mass transport and thus high resolution at high flow rates.

Stationary phases with specific molecular recognition properties, i.e., with predetermined selectivity, can be tailored using the molecular imprinting technique. A template molecule is added to suitable 
monomer(s), the system is polymerized and the template molecule is washed out. Chiral phases are prepared by using chiral template molecules. The polymers are easy to prepare, inexpensive and exhibit excellent physico-chemical and mechanical stabilities. For example, a chiral phase has been tailored by imprinting a peptide molecule into a polymer [69]. The influence of water on the recognition process and the roles of hydrogen bonding and of hydrophobic effects on the ligand selectivity have been discussed [70]. An example of a separation of D,L-enantiomers of dipeptides on an imprinted polymer is given in Fig. 1 [71].

Recently there has also been great development in stationary phases for preparative separations of peptides and proteins. An extensive list of the literature can be found in the reviews by Boschetti [72] and Narayanan [73], where tables of sorbents, their properties and commercial products can also be found. In general, classical soft gels based on dextran, diluted polyacrylamide and non-cross-linked agarose have gradually been replaced by more rigid materials, leading to improvements in the speed of separations through the use of higher mobile-phase flow rates, in the efficiency through the use of smaller and more regular stationary phase particles and in the resolution through the use of special separation mechanisms, such as affinity and hydrophobic interactions. On the other hand, the sorption capacity has not improved much compared with classical materials. Use is made of perfusion chromatography (see above), as well as of materials that combine the favourable sorption properties of soft gels with the rigidity of composite materials ('soft gel in a rigid shell').

\subsection{Separation systems}

\subsubsection{Normal-phase chromatography}

This technique is not common in peptide separations but it can be useful in specialized cases. For example, peptides produced by the cleavage of membrane proteins (4 to 50 amino acid residues) are amphiphilic and are thus difficult to solubilize in common polar and non-polar solvents. They undergo self-aggregation and are strongly adsorbed in chromatographic columns, due to their $\alpha$-helix structure in which the hydrophilic domain is located inside and the hydrophobic domain is on outside when it can interact

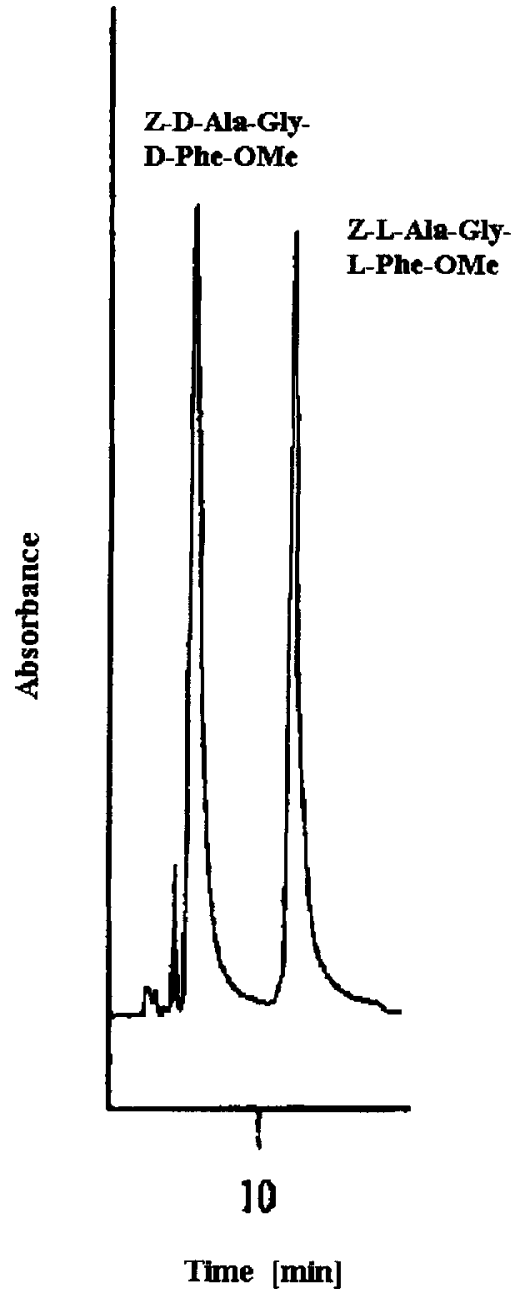

Fig. 1. A separation of a $100 \mu \mathrm{g}$ sample of a mixture of $\mathrm{Z}-\mathrm{L}-\mathrm{Ala}-$ Gly-L-Phe-OMe and Z-D-Ala-Gly-D-Phe-OMe on a chiral stationary phase imprinted with Z-L-Ala-Gly-L-Phe-OMe [71]. A $250 \times 4.6 \mathrm{~mm}$ column; mobile phase composed of solvents $A$ (chloroform+acetic acid, 9:1) and B (chloroform+acetic acid, $99: 1$ ), with a gradient of $A$ in $B$ ( 0 to 7 min: $0 \% A ; 7$ to 9 min: 0 to $100 \% \mathrm{~A} ; 9$ to $17 \mathrm{~min}: 100 \% \mathrm{~A} ; 12$ to $17 \mathrm{~min}: 100$ to $0 \% \mathrm{~A}$ ); flow rate, $1 \mathrm{ml} \mathrm{min}^{-1}$.

with the membrane lipid bilayer. RPC yields very poor separation in this case, but normal phase chromatography with an aminopropyl-modified silica stationary phase and a mobile phase of chloroform/methanol/ isopropylamine has been used successfully [74].

\subsubsection{Reversed-phase chromatography}

This technique is most widely used in separations of peptides and proteins for the reasons discussed in 
Section 4.2.1, where general information on the stationary phases is also given. Selected examples of separation systems are given below.

Most RPC separations of peptides are carried out with various silica-based, alkyl bonded phases permitting the detection of a difference in a single amino acid residue in chromatograms. The effects of changes in the immobilized alkyl chains have been discussed (e.g., [75]); it has been concluded that alkyls that are not longer than butyl are preferable for large peptide and protein separations, as it is possible to use mobile phases with higher water contents that do not cause pronounced denaturing of the solutes. In polar mobile phases the alkyl chains interact among themselves rather than with the mobile phase and collapse onto the support surface; the degree of denaturation is greater in the presence of long, freely moving alkyl chains. It follows from a study of the position of the alkyl chains with respect to the support surface and their mobility [76] that butyl chains lie almost perpendicular to the support surface at high ligand densities, whereas at a low ligand density they are strongly tilted or almost parallel to the surface.

The subject of hydrolytic instability of silica phases and the activity of residual silanols, as well as the ways taken to overcome them, have already been discussed; however, it should be pointed out that acetonitrile in mobile phases has a beneficial effect on the life-time of silica phases. To speed up separations of peptides and proteins, the Supelco company offers a wide-pore ( $300 \AA$ ) reversed phase SUPELCISIL, designed for peptide digests of human haemoglobin (an acetonitrile gradient in $0.1 \%$ aqueous trifluoroacetic acid) [77]; a mixture of peptides and proteins was separated in $90 \mathrm{~s}$ using this type of phase [78]. Fluorinated bonded stationary phases have been recommended for micellar RPC of small peptides [79], yielding a higher efficiency compared with alkyl-bonded phases, probably due to faster mass transport; the surfactant is adsorbed less and the efficiency is thus improved.

Because of the great diversity of peptide structures, no general system has been developed for their RPC separation. Peptides are generally best separated in acidic media. However, acidic and/or hydrophobic peptides are often difficult to dissolve and if they can be dissolved, they aggregate at $\mathrm{pH}$ values below 4 ; it is thus necessary to separate them at a $\mathrm{pH}$ of about 7. Most mobile phases contain an aqueous buffer and acetonitrile as the organic modifier, as the latter has a low UV absorbance and low viscosity and exhibits high elution strength and good selectivity. Isopropanol has similar favourable properties, but its viscosity is higher and thus the separation efficiency is poorer than that attained with acetonitrile.

A great proportion of the mobile phases used contain low concentration of trifluoroacetic acid (TFA) $(0.1$ to $0.2 \%)$ at a pH of about 2 [80] which acts as an ion-pairing agent and thus increases the retention, enhances the solubility of peptides and reduces electrostatic interactions with residual silanols; this substance does not absorb in the UV range used for the detection and is readily removed in preparative applications. Because of these favourable properties it is widely used not only in RPC but also in SEC. On the other hand, the drawbacks of this approach involve poor column stability, stationary phase bleeding, poor peak shape and low recoveries. Another approach is to add trimethyl ammonium phosphate [81]. Phosphoric acid facilitates the peptide elution at low acetonitrile concentrations and acts as a hydrophobic counter-ion to the free silanol groups on the silica support, thus suppressing peptide interactions with the silica. Ammonium acetate is used in separations of acidic peptides, whereas separations of strongly basic, hydrophilic peptides, rich in arginine, histidine and lysine, can be improved by adding heptafluorobutyric acid $(0.05$ to $0.1 \%)$ as an ion-pairing reagent. $\beta$ Mercaptoethanol is often added to maintain a reducing atmosphere protecting methionine from oxidation.

Small non-derivatized peptides can best be separated on a $\mathrm{C}-18$ phase with a purely aqueous mobile phase of $0.025 \mathrm{M}$ potassium dihydrogen phosphate buffer containing $0.1 \%$ TFA; amperometric detection at a copper electrode can be used [82]. Micellar mobile phases are also useful, especially in separations of small peptides (up to ca. 16 amino acid residues) [83]. The intensity of interaction with sodium dodecyl sulfate (SDS) micelles increases with increasing chain length of the peptide and with its increasing positive charge and is also affected by the amino acid sequence; on the other hand, partially hydrophobic peptides exhibit weak interactions with micelles.

To improve the resolution, peptide separations are often carried out at elevated temperatures when the sorption/desorption equilibria stabilize more rapidly $[84,85]$. However, it is sometimes useful to decrease 


\section{Leu-Pro}

$0^{\circ} \mathrm{C}$

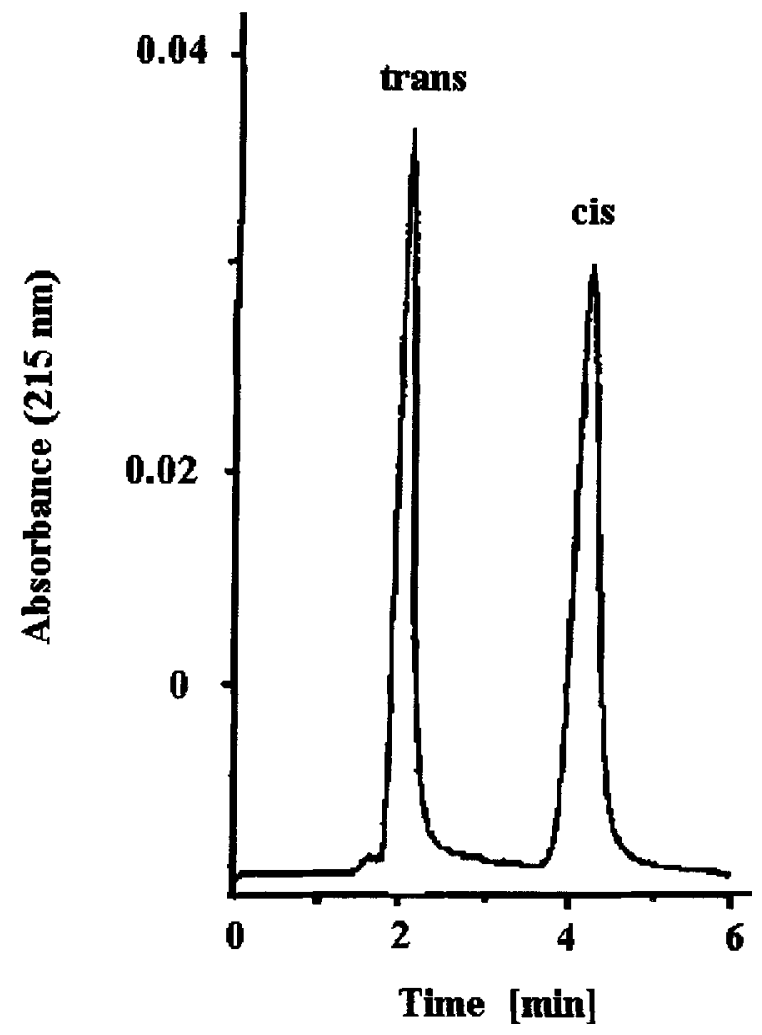

Fig. 2. A separation of the cis and trans conformers of Leu-Pro by $\mathrm{RPC}$ at a temperature of $0^{\circ} \mathrm{C}$ [86]. A $105 \times 4.6 \mathrm{~mm}$ column packed with $2 \mu \mathrm{m}$ pellicular silica-based $\mathrm{C}_{18}$ phase; mobile phase, a

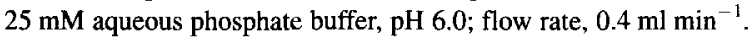

the temperature by immersing the column in an ice bath, in order to separate peptide conformers, as the establishment of the conformational equilibrium is retarded. For example, peptides with one or more rotationally hindered peptide bonds caused by the presence of proline and/or another $\mathrm{N}$-substituted amino acid residue in the solute molecule can be separated in this way [86] (Fig. 2), as can cis- and trans-peptide bond conformers of a cholecystokininrelated pentapeptide at $-17^{\circ} \mathrm{C}[87]$.

When surveying peptide RPC separations it becomes clear that the composition of the mobile phase affects the separation more than the kind of bonded stationary phase; this could be expected from the general character of RPC. This has been demon- strated, e.g., in Ref. [81] on the separation of insulins using two different mobile phases and three stationary phases (C-4, C-18 and phenyl); similar conclusions have been drawn for the separation of $\beta$-casomorphin peptides on C-8, C-18, C-30 and quaternary amino bonded phases [88].

Fast peptide separations have been attained using a stationary phase based on high-purity, non-porous, monodisperse silica beads $(1.5 \mu \mathrm{m})$, chemically modified with a short, branched-chain alkyl silane [89]. The material is rigid, sterically hindered and exhibits a long lifetime under harsh conditions $\left(70^{\circ} \mathrm{C}, \mathrm{pH} 1.9\right)$. When using short columns at elevated temperatures, the efficiency is improved, the detection limit is lowered and the time of analysis is short; the separation of tryptic fragments of bovine cytochrome $c$ on this stationary phase is depicted in Fig. 3.

An example of the use of the polymer-based reversed phase HEMA Bio $1000 \mathrm{C}-18$ is the identi fication, quantitation and preparation of the strongly basic polypeptide melittin and phospholipase $A_{2}$ from bee venom [90]. Melittin is irreversibly adsorbed on silica-based phases; the high efficiency and good peak shapes obtained with the HEMA phase are demonstrated in Fig. 4 for a gradient elution with a wateracetonitrile-TFA mobile phase.

An RPC stationary phase based on microspherical carbon has been recommended for the separation of peptides that are not retained on C-18 columns [91]. This material is non-polar, inexpensive and easy to clean by washing with alkaline solvents to remove adsorbed peptides. It has been tested on 133 peptides with an acetonitrile gradient of 10 to $70 \%$ in $0.1 \%$ aqueous TFA. The capacity factors depend on the peptide hydrophobicity, similar to silica-based sorbents, however, aromatic peptides are more strongly retained due to strong interaction with the graphite structure of the sorbent. The material is stable up to a temperature of $160^{\circ} \mathrm{C}$, where silica-based materials are degraded. Analogously, a porous graphitized carbon column and a mobile phase containing acetonitrile and TFA have been used for the separation of oligosaccharides, alditols and glycopeptides with MS detection [92]. This technique is complementary to RPC, with the advantage that peptides, glycopeptides, reducing oligosaccharides, silylated oligosaccharides and oligosaccharide alditols can be chromatographed under the same conditions. 


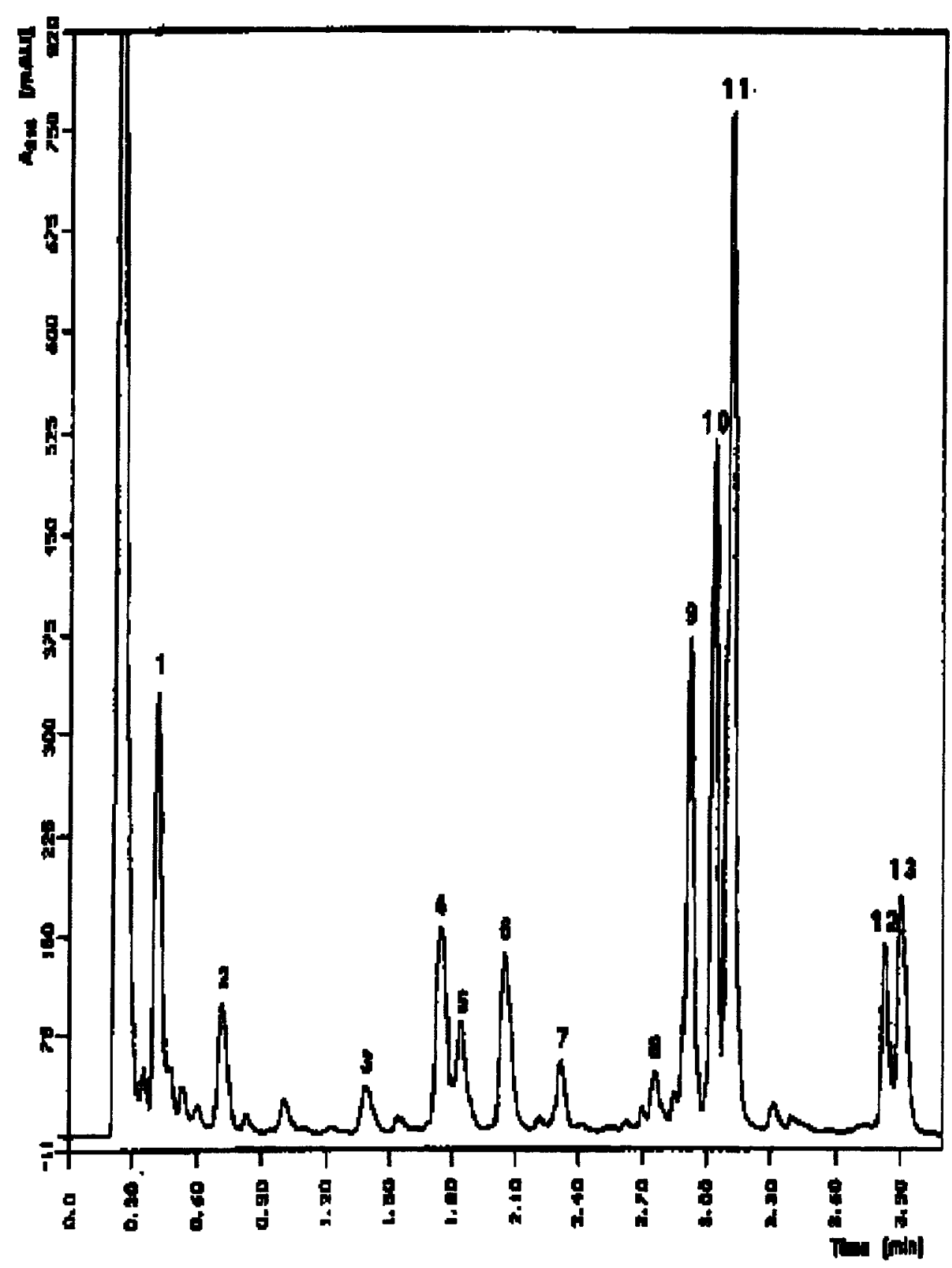

Fig. 3. A rapid separation of tryptic fragments of bovine cytochrome c [89]. A $33 \times 4.6 \mathrm{~mm}$ Kovasil-H column; mobile phase, A: $0.2 \mathrm{M}$ sodium perchlorate $+0.1 \%$ TFA, B: acetonitrile $/ 0.2 \mathrm{M}$ sodium perchlorate (70/30)+0.1\% TFA; gradient: $6 \%$ B to $12 \% \mathrm{~B}$ in $0.01 \mathrm{~min}, 12 \% \mathrm{~B}$ to $15 \% \mathrm{~B}$ in $0.79 \mathrm{~min}, 15 \% \mathrm{~B}$ to $25 \% \mathrm{~B}$ in $0.01 \mathrm{~min}, 25 \% \mathrm{~B}$ for $0.49 \mathrm{~min}, 25 \% \mathrm{~B}$ to $35 \% \mathrm{~B}$ in $0.01 \mathrm{~min}, 35 \% \mathrm{~B}$ for $1.99 \mathrm{~min}, 35 \% \mathrm{~B}$ to $100 \% \mathrm{~B}$ in $0.70 \mathrm{~min}$; flow rate, $1.2 \mathrm{ml} \mathrm{min}{ }^{1}$; temperature, $70^{\circ} \mathrm{C}$; sample volume, $10 \mu \mathrm{l}$; $\mathrm{UV}$ photometric detection at $215 \mathrm{~nm}$. 


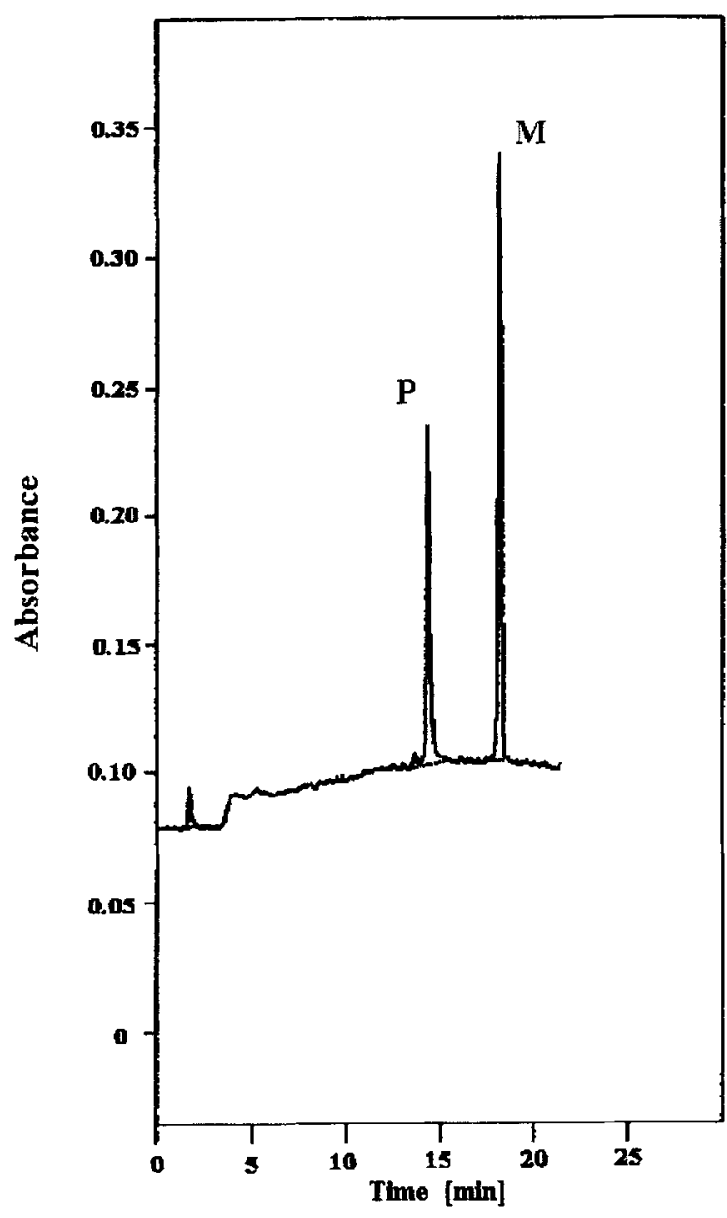

Fig. 4. A separation of the bee venom components by RPC on a HEMA column [90]. A $150 \times 3.3 \mathrm{~mm}$ HEMA Bio $1000 \mathrm{C}-18$ $(10 \mu \mathrm{m})$ column; eluent A: $0.22 \%$ TFA in water, eluent $\mathrm{B}: 0.2 \%$ TFA in acetonitrile, gradient from 0 to $50 \% \mathrm{~B}$ in $20 \mathrm{~min}$, from 50 to $100 \% \mathrm{~B}$ in $5 \mathrm{~min}$; UV photometric detection at $215 \mathrm{~nm}$; a $10 \mu 1$ sample.

Analysis of complex peptides from tryptic digest (peptide mapping) constitutes one step in the complicated elucidation of the protein primary structure. This task usually requires combinations of several separation techniques. For example, the tryptic digest of recombinant human extracellular superoxide dismutase was separated by SEC and the collected fractions were further separated by RPC; a CE separation was carried out in parallel [42] (Fig. 5). Mass spectrometric detection is often employed as a powerful identification technique. The use of microbore and capillary columns is advantageous [93-95].
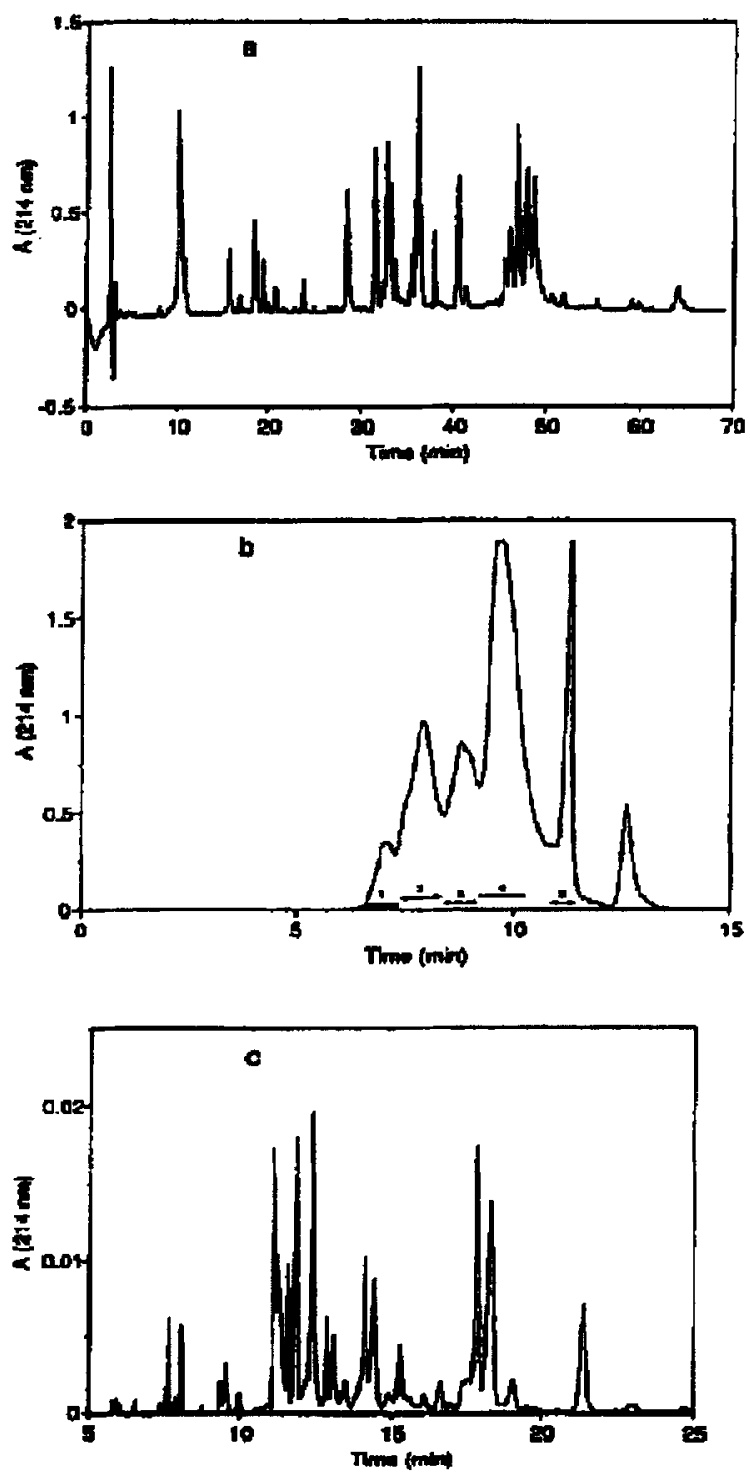

Fig. 5. Peptide mapping of recombinant human extracellular superoxide dismutase (EC-SOD) using a combination RPC, SEC. and CE [42]. (a) RPC; a $250 \times 2.0 \mathrm{~mm}$ Ultrasphere C18 column; gradient of acetonitrile in $0.1 \%$ aqueous TFA, 0 to $24 \%$ from 5 to $30 \mathrm{~min}$ and 24 to $36 \%$ from 30 to $60 \mathrm{~min}$; the column was then washed with a steep acetonitrile gradient to $60 \% \mathrm{ACN}$ followed by $10 \mathrm{~min}$ washing at this concentration before reequilibration to the initial conditions; flow rate, $0.25 \mathrm{mI} \mathrm{min}^{1}$, a $230 \mu \mathrm{g}$ sample. (b) SEC of a $400 \mu \mathrm{g}$ sample of EC-SOD; a $200 \times 9.4 \mathrm{~mm}$ polyhydroxyethyl aspartamide column; mobile phase, $0.2 \mathrm{M}$ sodium sulfate $+5 \mathrm{mM}$ potassium phosphate, $\mathrm{pH} 3.0$, containing $30 \%$

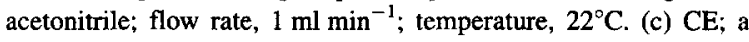
$50 \mathrm{~cm} \times 100 \mu \mathrm{m}$ fused silica capillary, $10 \mathrm{~s}$ pressure injection of samples diluted in $10 \mathrm{mM}$ phosphoric acid, $\mathrm{pH} 2.5 ; 20 \mathrm{kV}$; separating buffer, $0.1 \mathrm{M}$ phosphoric acid, $\mathrm{pH} 2.5$. 
Newly synthesized Dalargin analogues, nonapeptides from intrachinary regions A6-14 of insulin, IGF I and IGF II, have been separated both by RPC and CE; $\mathrm{CE}$ is preferable for peptides available in extremely small quantities [96]. For preparative chromatography, see the reviews by Boschetti [72] and Narayanan [73] (Section 4.1). Micropreparative HPLC of peptides and proteins has also been reviewed [97]. Micropacked columns are used to obtain small peak elution volumes (less than $100 \mu \mathrm{l}$ ) and thus to increase the peptide concentration for subsequent micromanipulations. An advantage of microcolumns lies in the use of low mobile phase flow rates (around $1 \mu 1 \mathrm{~min}^{-1}$ ), permitting direct coupling with an MS detector. Multidimensional column systems (SEC, IEC, RPC) are employed with compatible mobile phases. Cumulative recoveries of $89 \%$ have been obtained with a sample load of $500 \mathrm{pg}$ of protein standards.

\subsubsection{Chiral separations}

Resolution of peptide stereoisomers and amino acid enantiomers is necessary for the process and purity control of, e.g., foodstuffs and pharmaceuticals. Three approaches can be employed to solve this task:

- separations on chiral columns [98];

- separations on achiral stationary phases with mobile phases containing chiral selectors $[98,99]$;

- precolumn derivatization with chiral agents (e.g., enantiomers of $\beta$-methyl amino acid-containing peptides can be separated after derivatization with 1-fluoro-2,4-dinitrophenyl-5-L-alanine amide and $2,3,4,6$-tetra- $O$-acetyl- $\beta$-D-glucopyranosyl isothiocyanate $[100])$.

Cyclodextrins are most often used for the preparation of chiral columns and as chiral selectors in mobile phases. The chiral resolution is high when a hydrophobic amino acid (Phe) bears the chiral centre and is capable of forming an inclusion complex with the hydrophobic interior of the cyclodextrin; the differences in the hydrogen bonds of the $L$ - and $D$ - isomers with the cyclodextrin cavity then form the basis for the separation, but adsorption effects also play a role.

Macrocyclic antibiotics have also been used as chiral selectors (for a review see Ref. [101]). Chemically bonded antibiotics, e.g., vancomycin, ristocetin A, rifamycin [102] and teicoplanin [103], can be used

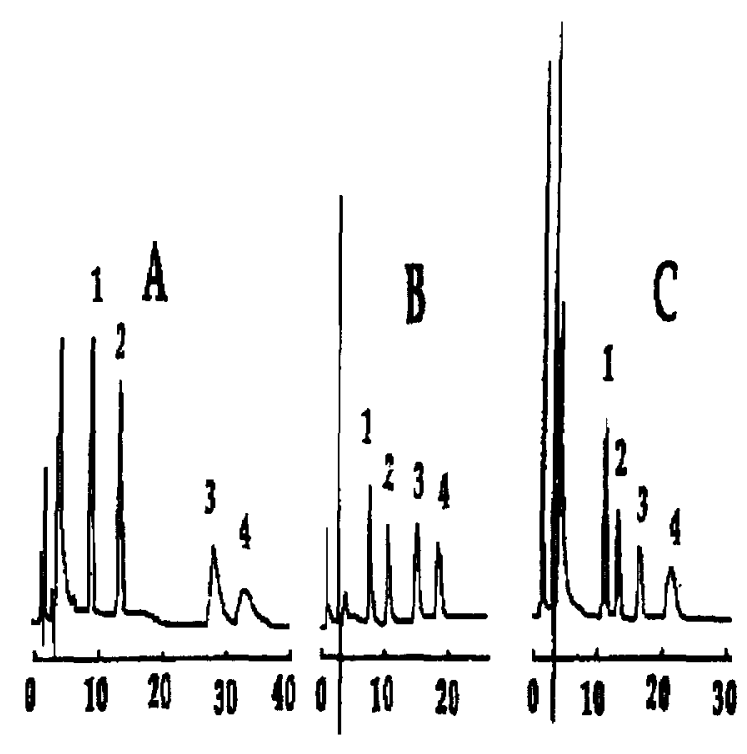

DLAL201-Ah

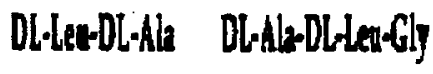

Fig. 6. A separation of dipeptide and tripeptide enantiomers [103]. A $250 \times 4.6 \mathrm{~mm}$ column packed with the Chirobiotic $\mathrm{T}$ phase with teicoplanin bonded to $5 \mu \mathrm{m}$ silica particles; mobile phase, ethanol+water, $60: 40$; flow rate, $1 \mathrm{ml} \mathrm{min}^{-1}$; UV photometric detection at $215 \mathrm{~nm}$; the time is given in minutes.

as efficient stationary phases for enantioseparations of amino acids and peptides. Simple mobile phases, usually aqueous ethanol, are used. D-amino acids are retained more strongly. Most di- and tripeptides contain two or more chiral centres; the selectivity can then be evaluated only if the pure enantiomers can be identified (Fig. 6).

The methods of immobilization of bovine serum albumin on silica and the effect of the organic modifier on the chiral recognition of derivatized amino acids have been studied [104]. Native $\beta$ - and $\gamma$-cyclodextrins have been used as chiral stationary phases for separations of derivatized amino acids and peptides (9-fluorenyl methyl chloroformate and its analogue) [105]; the number and positions of the glycyl moieties in glycyl-containing peptides affect the retention and the enantioselectivity.

Peptides as chiral selectors have been reviewed [106]. Synthetic peptides have been used in both normal- and reversed-phase chromatography. For example,dipeptides have been separated in the RPC 
mode on an L-Val-L-Ala-L-Pro bonded phase with water or an aqueous buffer as the mobile phase $[107,108]$. The dipeptides elute in the order of increasing hydrophobicity of their hydrocarbon side-chains and the capacity factors increase with increasing $\mathrm{pH}$.

\subsubsection{Size-exclusion chromatography}

SEC is advantageous as the first step in the separation of complex mixtures of a whole range of peptides, provided that the mobile phases used are compatible with biologically active compounds. As pointed out above, the SEC columns are prepared so that nonspecific interactions are minimized, however, most columns are still weakly anionic and slightly hydrophobic and thus deviations from ideal SEC behaviour are encountered. A series of synthetic peptides has been recommended for the monitoring of ideal and non-ideal behaviour of SEC columns [17]. The proposed five peptides form a series with repeating tenresidue units (800 to $4000 \mathrm{Da}$ ) and with increasing basicity ( 1 to 5 positively charged residues) (Table 2 ) and can be used for column calibration and for monitoring of ionic and hydrophobic interactions. A well calibrated column permits the determination of solute molecular masses with a precision close to that of absolute methods [109]. The peptides remain in a random coil configuration in both denaturing and non-denaturing mobile phases. Electrostatic effects can be suppressed by adding salts $(200 \mathrm{mM} \mathrm{KCl})$, but salt concentrations higher than $0.6 \mathrm{M}$ should be avoided in SEC.

The character of peptides varies and thus various $\mathrm{pH}$ values are required for their SEC separations, as the $\mathrm{pH}$ affects the net charge on the peptide and any nonspecific interactions between the solute and the sorbent [81]. The addition of an organic modifier (acetonitrile) decreases non-specific hydrophobic interactions of peptides with SEC stationary phases and increases the peptide solubility. $\mathrm{A}$ low $\mathrm{pH}$ is recommended for peptide SEC separations, except for strongly acidic peptides that are insoluble at low $\mathrm{pH}$ values. Increased buffer concentrations decrease the retention times because the peptides then appear larger due to ion pairing and solvation effects. Hydrophobic peptides, e.g., those containing non-polar side chains or aromatic systems, are strongly retained through hydrophobic interactions. Work at an elevated temperature $\left(50^{\circ} \mathrm{C}\right)$ is advantageous, as the linearity of the retention time vs. log molecular weight is then extended over a wider molecular weight range.

Polyvinyl pyrrolidone-coated silica packings have been used in the SEC of polypeptides [110]. These substances are synthesized by the interaction of the copolymer of vinyl methyl diethyl oxysiloxane and vinyl pyrrolidone with LiChrosorb Si 300 and 500 silicas. The coatings retain the wide-pore structure, are primarily hydrophilic but also exhibit some ionexchange properties which can, however, be suppressed by the addition of a salt; the optimum salt concentration is $0.2 \mathrm{M}$. Higher salt contents cause a hydrophobic interaction mechanism to prevail and polypeptides and proteins are eluted with a decreasing salt gradient.

Polyhydroxyethyl aspartamide combined with a mobile phase of $0.2 \mathrm{M}$ sodium sulfate, $5 \mathrm{mM}$ potassium phosphate ( $\mathrm{pH} 3$ ) plus $25 \%$ acetonitrile has further been recommended for the SEC of peptides [42].

Spheric silica particles of various pore sizes, 145 , 290 and $500 \AA$ (Biosep-SEC-S-2000, S-3000 and S4000 , respectively) were coated with hydrophilic film and used for the SEC of peptides and proteins with very good recovery and excellent stability [111].

\subsubsection{Ion-exchange chromatography}

IEC belongs among the oldest methods of peptide separation. This technique is complementary to RPC for characterization of peptides because most peptides exhibit net charges located either on a functional residue or on the $\mathrm{N}$ - or $\mathrm{C}$-terminus. At $\mathrm{pH}$ values equal to or lower than 3 , the peptide carboxyls are protonated and the IEC separation primarily depends on the number of basic residues (including the $\mathrm{N}$ terminus); hydrophobic interactions should be minimized. Therefore, both cation and anion exchange can be used, but the former predominates because most peptides are basic. Silica-based materials are unsuitable for anion-exchange chromatography of peptides, as the $\mathrm{pH}$ values required for deprotonation lead to degradation of silica.

IEC is especially important in separations of strongly basic peptides, as RPC often fails to separate these substances due to the low hydrophobicity/hydrophilicity ratio of the peptide molecules. Further advantages of IEC include mild separation conditions that maintain the biological activity of peptides, a high 
loading capacity and the possibility of preconcentrating the sample by trapping the peptides at the column head [112]. A salt gradient is usually employed, from pure buffer to a buffer and salt mixture. The retention depends on the kinds and concentrations of the buffer and displacing salt and the $\mathrm{pH}$ whose variation is, of course, limited by the $\mathrm{pH}$-dependent solubility and/or stability of the peptides. Hydrophobic interactions complicate IEC separations and can be suppressed by adding an organic modifier, preferably acetonitrile.

In some separations, ion-exchange and hydrophobic interactions can be combined to attain good peptide separations. Small cationic peptides from a tryptic digest of $\kappa$-casein have been separated [113] using the highly hydrophobic cation exchanger S-Hyper D consisting of a solid, porous mineral oxide core coated with a thin layer of polystyrene and a soft threedimensional cross-linked hydrogel located within the pores of the rigid structure and modified with sulphonated active groups. A gradient of sodium chloride in sodium acetate was used for elution at $\mathrm{pH} 4$.

Similar ion-exchange/hydrophobic separations can be carried out with the purely polymeric HEMA sorbents described above. The HEMA Bio $1000 \mathrm{CM}$ weak cation exchanger (the carboxymethyl active group) and the HEMA Bio 1000 SB strong cation exchanger (the sulfobutyl group) have been used in separations of amino acids and small peptides with a purely aqueous mobile phase of $0.002 \mathrm{M}$ potassium dihydrogen phosphate of $\mathrm{pH} 5.5[114,115]$. The retention of dipeptides decreases with increasing mobile phase ionic strength in accordance with the ionexchange mechanism, but the hydrophobicity of aromatic amino acids present in some of the peptides also plays a role. The peptides formed by enzymatic degradation of oxytocin have been separated on the HEMA Bio 1000 SB strong cation exchanger [116]. Methanol added to the aqueous mobile phase improves the solubility of larger peptides.

A new hydrophilic polystyrene-divinyl benzene strong cation exchanger (sulfonic acid groups) has been prepared for rapid analyses of large peptides and proteins [117], as have modified cellulose acetate membranes containing various ion-exchange groups [118]; the latter can only be used at low pressures (up to $7 \mathrm{bar})$. A small-particle $(3 \mu \mathrm{m})$, non-porous polymeric stationary phase with a polyethylene imine surface phase has been used for anion-exchange separations of large peptides and proteins at high $\mathrm{pH}$ values [119]; experimental times are very short (less than $60 \mathrm{~s}$ ). A strong cation exchanger, polysulfoethyl aspartamide, exhibits very good selectivity for peptides, and the peptide retention increases with increasing positive charge on the peptides $[120,121]$. More than 60 peptides ranging from 5 to 20 amino acid residues have thus been separated in a narrow-bore column using a gradient of sodium chloride in a phosphate mobile phase of $\mathrm{pH} 3.0$ containing acetonitrile [120].

\subsubsection{Hydrophobic interaction chromatography}

HIC has been known for many years and practised with the use of soft hydrophilic gels which have usually been chemically modified to increase the hydrophobic interaction with polypeptides and proteins. Recently, rigid HIC stationary phases have been developed, based on silica modified with ether or alkyl ligands. The main advantage of HIC separations over RPC lies in the fact that mild hydrophobicity of the stationary phase and high ionic strength of the mobile phase help to maintain polypeptides and proteins in their native state - for a comparison of RPC and HIC conditions see Table 3 [24].

An example of the use of HIC with a stationary phase of silica modified with polyethylene glycol can be found in Ref. [122].

Table 3

Comparison of RPLC and HIC [24]

\begin{tabular}{|c|c|c|}
\hline Parameter & RPLC & HIC \\
\hline \multicolumn{3}{|l|}{ Stationary phase } \\
\hline Interaction & Dispersion & Dispersion \\
\hline Ligand type & $\mathrm{C} 8-\mathrm{C} 18$ & $\mathrm{C} 2-\mathrm{C} 4$, phenyl, $\mathrm{CH}_{4}$ \\
\hline Ligand density & High & Low \\
\hline Hydrophobicity & Strong & Moderate \\
\hline \multicolumn{3}{|l|}{ Mobile phase } \\
\hline Type & $\begin{array}{l}\text { Aqueous-organic } \\
\mathrm{MeOH}, \mathrm{ACN}\end{array}$ & Solutions of salts \\
\hline Operation & Gradient & Reversed gradient \\
\hline \multicolumn{3}{|l|}{ Protein: } \\
\hline Structure on st.ph. & Unfolded & Native (folded) \\
\hline Dominant feature & $\begin{array}{l}\text { Overall } \\
\text { hydrophob. } \\
\text { primary sequence }\end{array}$ & $\begin{array}{l}\text { Surface } \\
\text { hydrophob. }\end{array}$ \\
\hline Loss of biol.act. & Considerable & Small \\
\hline
\end{tabular}




\subsubsection{Affinity chromatography}

In contrast to all the techniques discussed above which are based on relatively simple physico-chemical interactions between the solutes and the stationary and mobile phases, high-performance affinity chromatography (HPAC) depends on highly specific biological interactions in which the primary physicochemical properties are combined into very complex, finely tuned effects of molecule recognition. The main advantages of HPAC are very high selectivity and mild separation conditions from the point of view of solute denaturation.

Peptides are often used as stationary phase ligands $[123,124]$. Difficulties may then arise caused by poor accessibility for solute binding because of the small size of peptide molecules. This is solved either by attaching spacers to the small peptide (e.g., the Nu-Gel $\mathrm{H}$-AF support has a spacer of $12 \AA$ attached to a silica support), or a protein is used as the ligand.

Conventional HPAC has limited application and is restricted to those peptides or proteins that are capable of specific binding to the immobilized affinity counterpart. This complications can be alleviated by introducing a specific binding property into the peptide or protein of interest through genetic fusing of an affinity tail in to its N-or C-terminus (see, c.g. [125]). Such an affinity tail introduces unique binding properties to the target peptide and yields affinity columns with high recoveries. For example, the $\mathrm{Ca}$ (II)-dependent protein calmodulin can be used as the affinity tail that binds to many peptides [125]; $\mathrm{Ca}$ (II) is then removed by complexation with EDTA.

Irregular silica or glass beads are mostly used as supports. They are commercially available and contain various side chains necessary for immobilization of peptides or proteins (e.g., epoxy or thiol groups). These materials are usually prepacked in columns and the appropriate immobilization can be carried out in situ. Glass beads with controlled porosity, coated with a hydrophobic, non-ionic carboxylate film to decrease non-specific interactions, can also be used. An example of immobilization of the glycopeptide $\mathrm{N}$-glycosidase $F$ on various polymeric and silica supports can be found in Ref. [126].

Immobilized metal-ion affinity chromatography (IMAC) can be used for purification of synthetic peptides, with supports containing immobilized $\mathrm{Cu}$ (II) or $\mathrm{Ni}(\mathrm{II})[127,128]$. The interaction of these metal ions with unprotonated $\alpha$-amino groups of peptides (provided that all the other unreacted amino groups are blocked by acetylation and strongly interacting amino acids, e.g. Hys, Trp and Cys, are absent) is sufficiently selective to permit purification in a single step. The interaction depends on the $\mathrm{pH}$ and attains a maximum at $\mathrm{pH} 7.5$ for $\mathrm{Cu}(\mathrm{II})$ and 8.5 for $\mathrm{Ni}$ (II). At a lower $\mathrm{pH}$, the $\alpha$-amino group is protonated and, at high $\mathrm{pH}$ values, the metal ions are transferred to the peptides. The Ni(II) sorbent exhibits higher selectivity and affinity than the $\mathrm{Cu}$ (II) sorbent. The retention behaviour of peptides on a silica phase with immobilized poly(vinylimidazole)-Cu(II) has been studied [129]. Peptides containing one histidine residue and sometimes one tryptophan residue are strongly retained and can be eluted only by the addition of a complexing agent to the mobile phase. $O$-phosphoserine immobilized on epoxy-activated Sepharose CL-4B has also been proposed as a chelating ligand, in combination with $\mathrm{Al}^{3+}, \mathrm{Fe}^{3+}, \mathrm{Ca}^{2+}, \mathrm{Yb}^{3+}$ and $\mathrm{Cu}^{2+}[130]$ for IMAC.

\section{References}

[1] C.T. Mant, R.S. Hodges (Eds.), High-Performance Liquid Chromatography of Peptides and Proteins: Separation, Analysis, and Conformation, CRC Press, Boca Raton, Ann Arbor, Boston, London 1991, p. 5.

[2] T.J. Sereda, C.T. Mant, A.M. Quinn, R.S. Hodges, J. Chromatogr. 646 (1993) 17.

[3] M.G. Khaledi, A.H. Rodgers, Anal. Chim. Acta 239 (1990) 121.

[4] D. Guo, C.T. Mant, A.K. Taneja, J.M.R. Parker, R.S. Hodges, J. Chromatogr. 359 (1986) 499.

[5] C. Chabanet, M. Yvon, J. Chromatogr. 599 (1992) 211.

[6] A.W. Purcell, M.I. Aguilar, M.T.W. Hearn, J. Chromatogr. 593 (1992) 103.

[7] M.C.J. Wilce, M.I. Aguilar, M.T.W. Hearn, J. Chromatogr. 536 (1991) 165

[8] M.C.J. Wilce, M.I. Aguilar, M.T.W. Hearn, J. Chromatogr. 548 (1991) 105

[9] C. Schöneich, S.K. Kwok, G.S. Wilson, S.R. Rabel, J.F. Stobaugh, T.D. Williams, D.G.V. Velde, Anal. Chem., 65 (1993) 67R.

[10] C. Schöneich, A.F.R. Hühner, S.R. Rabel, J.F. Stobaugh, S.D.S. Jois, C.K. Larive, T.J. Siahaan, T.C. Squier, D.J. Bigelow, T.D. Williams, Anal. Chem. 67 (1995) 155R.

[11] J. Stahlberg, B. Jönsson, Anal. Chem. 68 (1996) 1536.

[12] Y. Kato, S. Nakatani, T. Kitamura, Y. Yamasaki, T. Hashimoto, J. Chromatogr. 502 (1990) 416. 
[13] N. Ninura, H. Itoh, Mol. Biotechnol. 5 (1996) 11.

[14] C.T. Mant, R.S. Hodges, in: C.T. Mant, R.S. Hodges (Eds.), The Use of Peptide Standards for Monitoring Ideal and Nonideal Behaviour in Cation-Exchange Chromatography, High-Performance Liquid Chromatography of Peptides and Proteins: Separation, Analysis, and Conformation, CRC Press, Boca Raton, Ann Arbor, Boston, London, 1991, p. 171.

[15] C.T. Mant, R.S. Hodges, in: C.T. Mant, R.S. Hodges (Eds.), Requirements for Peptide Standards to Monitor Column Performance and the Effect of Column Dimensions, Organic Modifiers, and Temperature in Reversed-Phase Chromatography, High-Performance Liquid Chromatography of Peptides and Proteins: Separation, Analysis, and Conformation, CRC Press, Boca Raton, Ann Arbor, Boston, London, 1991, p. 289.

[16] C.T. Mant, R.S. Hodges, in: C.T. Mant, R.S. Hodges (Eds.), The Use of Peptide Standards for Monitoring Non-ideal Behaviour due to Underivatized Silanols in Reversed-Phase Chromatography, High-Performance Liquid Chromatography of Peptides and Proteins: Separation, Analysis, and Conformation, CRC Press, Boca Raton, Ann Arbor, Boston, London, 1991, p. 297.

[17] C.T. Mant, R.S. Hodges, in: C.T. Mant, R.S. Hodges (Eds.), The Use of Peptide Standards for Monitoring Ideal and Nonideal Behaviour in Size-Exclusion Chromatography, HighPerformance Liquid Chromatography of Peptides and Proteins: Separation, Analysis, and Conformation, CRC Press, Boca Raton, Ann Arbor, Boston, London, 1991, p. 125.

[18] J.J. Kirkland, M.A. van Straten, H.A. Claessens, J. Chromatogr. A. 691 (1995) 3.

[19] H.A. Claessens, J.W. van Straten, J.J. Kirkland, J. Chromatogr. A 728 (1996) 259.

[20] G. Rippel, E. Alattyani, L. Szepesy, J. Chromatogr. 668 (1994) 301 .

[21] H.A. Claessens, J.W. de Haan, L.J.M. van de Ven, P.C. de Bruijn, C.A. Cramers, J. Chromatogr. 436 (1989) 345.

[22] M.J.J. Hetem, Chemically Modified Silica Surfaces in Chromatography, A Fundamental Study, Ph. D Thesis, Technical University, Eindhoven, The Netherlands, ISBN 37785-2030-X, Hüthig Inc., Heidelberg, FGR, 1993.

[23] A. Bede, G. Rippel, L. Szepesy, H.A. Claessens, J. Chromatogr. 728 (1996) 179.

[24] L. Szepesy, G. Rippel, J. Chromatogr. 668 (1994) 337.

[25] K.K. Unger (Ed.), Packing and Stationary Phases in Chromatographic Techniques, Chromatogr. Sci. Series, Vol. 47, Marcel Dekker, New York, 1990.

[26] H. Engerhardt, H. Löw, W. Götzinger, J. Chromatogr. 544 (1991) 371.

[27] M.J. Walters, J. Assoc. Off. Anal. Chem. 70 (1987) 465.

[28] K. Kimata, K. Iwaguchi, S. Onishi, K. Jinno, R. Eksteen, K. Horoya, M. Asaki, N. Tanaka, J. Chromatogr. Sci. 27 (1989) 721.
[29] B.A. Bidlingmeyer, S.N. Deming, W.P. Price, B. Schoh, M. Petrusek, J. Chromatgr. 186 (1979) 419.

[30] S.V. Galushko, Chromatographia 36 (1993) 39.

[31] C. Horváth, W.R. Melander, J. Molnăr, Anal. Chem. 49 (1977) 142.

[32] P. Jandera, J. Rozkošná, J. Chromatogr. 556 (1991) 145.

[33] T. Hamoir, F.C. Sanchez, B. Bourguignon, D.L. Massart, J. Chromatogr. Sci. 32 (1994) 488.

[34] A. Smilde, Multivariate Calibration of Reversed-phase Chromatographic Systems, Ph.D. Thesis, University of Groningen, The Netherlands, 1990.

[35] L.A. Cole, J.G. Dorsey, Anal. Chem. 64 (1992) 1317.

[36] A.B. Scholten, Molecular Surface Structure of Modified Silicas for Chromatography, Their Relation to Stationary Phase Performance and Stability, Ph. D Thesis, Eindhoven University of Technology. The Netherlands, 1996.

[37] A.B. Scholten, H.A.Claessen, J.W. de Haan, C.A. Cramers, J. Chromatogr., accepted.

[38] M.R.P. Breuer, H.A. Claessens, C.A. Cramers, Chromatographia 38 (1994) 137.

[39] G. Szepesy, How To Use Reversed-Phase HPLC, VCH Publishers, New York, 1992.

[40] G. Nyberg, K. Sanderson, P. Andrén, M. Thörnwall, M. Einarsson, B. Danielson, F. Nyberg, J. Chromatogr. A 723 (1996) 43.

[41] T. Janáky, E. Szabó, L. Baláspiri, B. Adi, B. Penke, J. Chromatogr. B 676 (1996) 7.

[42] M. Strömqvist, J. Chromatogr. A 667 (1994) 304.

[43] H. Hanson, K. Unger, LC-GC Int. 9 (1996) 650.

[44] H. Hanson, K. Unger, LC-GC Int. 9 (1996) 741.

[45] F. Honda, H. Honda, M. Koishi, J. Chromatogr. 609 (1992) 49.

[46] D. Corradini, K. Kalghatgi, C. Horváth, J. Chromatogr. A. 728 (1996) 225.

[47] M. Grün, A.A. Kurganov, S. Schacht, F, Schuith, K.K. Unger, J. Chromatogr. A 740 (1996) 1.

[48] A. Kurganov, U. Trüdinger, I. Isaeva, K. Unger, Chromatographia 42 (1996) 217.

[49] H.-J. Wirth, K.-O. Eriksson, P. Holt, M. Aguilar, M.T. Hearn, J. Chromatogr. 646 (1993) 129.

[50] H.-J. Wirth, M.T. Hearn, J. Chromatogr. 646 (1993) 143.

[51] Lifang Sun, A.V. McCormick, P.W. Carr, J. Chromatogr. A 658 (1994) 465.

[52] J. Čoupek, I. Vinš, J. Chromatogr. A 658 (1994) 391.

[53] S.L. Wu, K. Benedek, B.L. Karger, J. Chromatogr. 359 (1987) 3.

[54] N.B. Afeyan, N.F. Gordon, I. Maszaroff, L. Várady, S.P. Fulton, Y.B. Yang, F.E. Regnier, J. Chromatogr. 519 (1990) 1.

[55] A.F. Liapis, M.A. McCoy, J. Chromatogr. 599 (1992) 87.

[56] A.E. Rodrigues, J.M. Loureiro, C. Chenou, M. Rendueles de la Vega, J. Chromatogr. B 664 (1995) 233.

[57] M. McCoy, K. Kalghatgi, F.E. Regnier, N. Afeyan, J. Chromatogr. A 743 (1996) 221. 
[58] S. Rout, P.H. Corran, P.J. Gaffney, J. Chromatogr. B 660 (1994) 390.

[59] S. Hjertén, J.L- Liao, R. Zhang, J. Chromatogr. 473 (1989) 273.

[60] J.-L. Liao, R. Zhang, S. Hjertén, J. Chromatogr. 586 (1991) 21.

[61] S. Hjertén, K. Nakazato, J. Mohammad, D. Eaker, Chromatographia 37 (1993) 287.

[62] S. Hjertén, J. Mohammad, K. Nakazaro, J. Chrumatogr. 646 (1993) 121.

[63] F. Švec, J.M.J. Fréchet, Anal. Chem. 64 (1992) 820.

[64] Q.C. Wang, F. Švec, J.M.J. Fréchet, Anal. Chem. 65 (1993) 2243.

[65] Q.C. Wang, F. Švec, J.M.J. Fréchet, J. Chromatogr. A 669 (1994) 230.

[66] Y.M. Li, J.L. Liao, K. Nakazato, J. Mohammad, L. Terenius, S. Hjertén, Anal. Biochem. 223 (1994) 153.

[67] F. Švec, J.M.J. Fréchet, Macromol. Symp. 110 (1996) 203.

[68] T.B. Tennikova, F. Svec, J. Chromatogr. 646 (1993) 279.

[69] I.A. Nicholls, O. Ramström, K. Mosbach, J. Chromatogr. A 691 (1995) 349.

[70] L.I. Andersson, I.A. Nicholls, K.Mosbach, in: G. Street (Ed.), Highly Selective Separation in Biotechnology, Blackie, London, 1994, Ch. 9, p. 206.

[71] M. Kempe, K. Mosbach, J. Chromatogr. A 691 (1995) 317.

[72] E. Boschetti, J. Chromatogr. A 658 (1994) 207.

[73] S.R. Narayanan, J. Chromatogr. A 658 (1994) 237.

[74] K.A. Lerro, R. Orlando, H. Zhang, P.N.R. Usherwood, K. Nakanishi, Anal. Biochem 215 (1993) 38.

[75] R.P.W. Scott, C.F. Simpson, J. Chromatogr. Sci. 30 (1992) 59.

[76] I. Yarovsky, M.-I. Aguilar, M.T.W. Hearn, J. Chromatogr. A 660 (1994) 75.

[77] Supelco catalogue, 1995, p. 193.

[78] W. Kopaciewicz, E. Kellard, G.B. Cox, J. Chromatogr. A 690 (1995) 9.

[79] S. Yang, L.F. Resotko Kruk, M.G. Khaledi, J. Chromatogr. A. 664 (1994) 1.

[80] H.P.J. Bennett, C.A. Browne, S. Solonun, J. Liq. Chromatogr. 3 (1980) 1353.

[81] C. Miller, J. Rivier, Biopolymers (Peptide Science) 40 (1996) 265.

[82] K. Štulík, V. Pacáková, G. Jokuszies, J. Chromatogr. 436 (1988) 334.

[83] L. Lu, P. Lundahl, J. Chromatogr. A 741 (1996) 49.

[84] W.S. Hancock, R.C. Chloupek, J.J. Kirkland, L.R. Snyder, J. Chromatogr. A 686 (1994) 31.

[85] R.C. Chloupek, W.S. Hancock, B.A. Marchylo, J.J. Kirkland, B.E. Boyes, L.R. Snyder, J. Chromatogr. A 686 (1994) 45.

[86] A. Kálmán, F. Thunecke, R. Schmidt, P.W. Schiller, C. Horváth, J. Chromatogr. A 729 (1996) 155.

[87] M. Lébl, S. Fang, V.J. Hruby, J. Chromatogr. 586 (1991) 145.
[88] F. Kálmán, T. Cserháti, K. Valkó, K. Neubert, Anal. Chim. Acta 268 (1992) 247

[89] R. Ohmacht, I. Kiss, Chromatographia 42 (1996) 595.

[90] V. Pacáková, K. Štulík, P.T. Hau, I. Jelínek, I. Vinš, D. Sýkora, J. Chromatogr. 700 (1995) 187.

[91] S. Yamaki, T. Isobe, T. Okuyama, T. Shinoda, J. Chromatogr. A, 728 (1996) 189; J.Chromatogr. A, 729 (1996) 143.

[92] M.J. Davies, K.D. Smith, R.A. Carruthers, W. Chai, A.M. Lawson, E.F. Housell, J. Chromatogr. 646 (1993) 317.

[93] J.F. Banks, Jr., J. Chromatogr. A 743 (1996) 99.

[94] Y.L.F. Hsieh, H.Q. Wang, C. Elicone, J. Mark, S.A. Martin, F. Regnier, Anal. Chem. 68 (1996) 455.

[95] M.J.-F. Suter, B.B. DaGue, W.T. Moore, S. Lin, R.M. Caprioli, J. Chromatogr. 553 (1991) 101.

[96] V. Pacáková, J. Suchánková, K. Štulík, J. Chromatogr. B 681 (1996) 69

[97] E.C. Nice, Biopolymers (Peptide Science) 40 (1996) 319.

[98] D.W. Armstrong, Anal. Chem. 59 (1987) 87A.

[99] T. Takeuchi, J. Microcol, Sep. 4 (1992) 209.

[100] A. Péter, G. Tóth, G. Török, D. Tourwé, J. Chromatogr. A 728 (1996) 455.

[101] T.J. Ward, LC-GC 9 (1996) 429.

[102] D.W. Armstrong, K. Rundlett, J.R. Chen, Chirality 6 (1994) 496.

[103] A. Berthod, Y. Liu, C. Bagwill, D. Armstrong, J. Chromatogr.A 731 (1996) 123.

[104] K. Harada, Q. Yuan, M. Nakayama, A. Sugii, J. Chromatogr. A 740 (1996) 207.

[105] Y. Tang, J. Zukowski, D.W. Armstrong, J. Chromatogr. A 743 (1996) 261.

[106] S.G. Allenmark, S. Andersson, J. Chromatogr. A 666 (1994) 167.

[107] G.W.-K. Fong, E. Grushka, Anal. Chem. 50 (1978) 1154.

[108] W.A. Howard, T.-B. Hsu, L.B. Rogers, D.A. Nelson, Anal. Chem. 57 (1985) 606.

[109] L. Hagel, J. Chromatogr. 648 (1993) 19.

[110] A. Kurganov, Yu. Puchkova, V. Davankov, F. Eisenbeiss, J. Chromatogi. A 663 (1994) 163.

[111] F. Ahmed, B. Modrek, J. Chromatogr. 599 (1992) 25.

[112] G. Malmquist, N. Lundell, J. Chromatogr. 627 (1992) 107.

[113] S. Bouhallab, G. Henry, E. Boschetti, J. Chromatogr. A 724 (1996) 137.

[114] H. Wang, V. Pacáková, K. Štulík, J, Chromatogr. 509 (1990) 245.

[115] K. Štulîk, V. Pacáková, H. Wang, J. Chromatogr. 552 (1991) 439.

[116] W. Heping, V. Pacáková, K. Štulík, T. Barth, J. Chromatogr. 519 (1990) 244.

[117] Y.-B. Yang, K. Harrison, J. Kindsvater, J. Chromatogr. A 723 (1996) 1.

[118] The Reporter (Supelco), Vol.15, No.5, 1996, p. 11.

[119] R.G. Hatch, J. Chromatogr. Sci. 31 (1993) 469. 
[120] D.L. Crimmins, J. Gorka, R.S. Thoma, B.D. Schwartz, J. Chromatogr. 443 (1988) 63.

[121] J.J. Dorman, B.J. Shiell, J. Chromatogr. 646 (1993) 193.

[122] R.G. Hatch, J. Chromatogr. Sci. 28 (1990) 210.

[123] J.E. Van Eyk, C.T. Mant, R.S. Hodges, High Peformance Affinity Chromatography of Peptides and Proteins, p. 479.

[124] T.M. Phillips, Theory and Practical Aspects of HighPerformance Immunoaffinity Chromatography, p.507.

[125] N.G. Hentz, V. Vukasinovic, S. Daunert, Anal. Chem. 68 (1996) 1550 .
[126] C. Schaumann, F. Oesch, K.K. Unger, R.J. Wieser, J. Chromatogr. A 646 (1993) 227.

[127] P. Hansen, G. Lindeberg, L. Andersson, J. Chromatogr. 627 (1992) 125.

[128] P. Hansen, L. Andersson, G. Lindeberg, J. Chromatogr.A 723 (1996) 51.

[129] M.-C. Millot, F. Hervé, B. Sébille, J. Chromatogr. B 664 (1995) 55

[130] M. Zacharion, I. Traverso, M.T. Hearn, J. Chromatogr. A 646 (1993) 107. 